\title{
School Leaders' Innovation Managements and Organizational Stress: A Relational Model Study*
}

\author{
Esef Hakan Toytok \\ Department of Educational Sciences, Faculty of Education, Siirt Üniversitesi, Turkey
}

Copyright $(2016$ by authors, all rights reserved. Authors agree that this article remains permanently open access under the terms of the Creative Commons Attribution License 4.0 International License

\begin{abstract}
This century is a century in which vertiginous rapid change is experienced. In each day, new innovations are being part of our lives. For this reason, innovation term is a dynamic concept that emerges in every field and it is inside of life. "Innovation" is an English term but it is adopted in daily life in Turkish as "inovasyon" with the same meaning. The world is rapidly changing and developing, so the understanding of innovation term as a dynamic continuum should be guided and managed in a correct way. Schools are also affected from this situation both directly and indirectly. School leaders have some duties and responsibilities to gain the positive aspects of the influence and to avoid from negative aspects. While school leaders provide this interaction that is based upon innovation, they should preserve their schools' existing balance, and they should carry out innovations in a correct proportion, shape and time. Otherwise, they may harm their schools' organizations or functions. Another variable that may harm schools' organizations or functions is organizational stress. Organizational stress is termed as a situation that may supply divergence from normal functions of people. It may differ with respect to people and is caused by the relations between person and organization. In any organization, the increase in the organizational stress level may result with divergence of workers from normal functions. The cause of this is the psychological and physiological fatigue of workers. Under this circumstance, behaviors of the person may be affected both negatively and directly. The aim of this study is to investigate the level of relationship between school leaders' innovation management approaches and organizational stress. Descriptive relational screening model is used throughout the study. The population of the study consist of 940 elementary, 911 middle, and 649 high school teachers in Kocasinan province of Kayseri city. Stratified sampling procedure is used and nearly 1000 inventory is distributed to all school levels. 171 elementary, 178 middle and 164 high school teachers replied the data collection tool. Data are analyzed using R 3.2.4 and SPSS 21.00. In the light of the results, significant but small relationships in the negative direction are observed across organizational culture and structure factor of school leaders' innovation management
\end{abstract}

behaviors and (i) clustering structure, (ii) role structure, and (iii) cultural structure factors of organizational stress. In addition, again small but significant relationship in the negative direction is observed across project management factor of school leaders' innovation management behaviors and cultural structure factor of organizational stress.

Keywords School Leaders, Innovation, Innovation Management, Organizational Stress

\section{Introduction}

Change and innovation seem to grow rapidly in the century we live in. Individuals, societies, organizations... briefly everything are necessarily affected in a positive or negative way by this change and innovation processes. While it does not seem possible to avoid this affect it is also not meaningful. The important thing is to be able to know how to benefit from this change and innovation phenomena in accordance to our individual or organizational purposes, because an uncontrolled innovation or power of change may give serious and permanent damages to the existing structure. In this sense, it is necessary to manage and control the power of change and innovation. Correspondingly we see that lately under the name of "innovation management" a concept has emerged. When we examine conceptually, innovation is mostly under debate as a new idea, product, service or system $[2,12,36]$. As is known, like all organizations educational organizations too are affected by the changes occurring around its environment. However, the presence of educational organizations' responsibility to start change is the leading basic feature which distinguishes educational organizations from other organizations [24]. In order to progress and improve, an organization needs the phenomenon of "innovation management". Taking the innovation to be held in a multiple accession process will certainly be more democratic. Difficulties are experienced in the acceptance of transition to the $4+4+4$ education system, which is a radical change and innovation in our education 
system, as this multiple accession process was ignored [13]. In the organizational processes of the administrators, they should pay attention to these and strengthen the organizational structures. In addition to this, according to Douglas, Overstreet and Hazen [11], managing the innovations properly is quite effective on improving the performances of employees in the organization. As is known, the manners of administrator are also quite effective on reaching the goals of an organization [3].

The irrepressible progress occurring in technology and science has caused the change of administrator concept by affecting it too and led to the emergence of leadership concept instead. Now we see that the concept of leadership is used in the schools instead of the concept of school administrator. Leadership is a notion which requires supervisory skills such as taking more responsibility than the administrators do, gaining a visional point of view and making an impact. Schools need an effective leader in order to develop a shared and supported vision or visions. In the management process, style of the leader is effective on both organization and employees [19]. Since they are in a social and open organization structure, schools are affected by what is happening around their environments and also affect these environments. In Toytok's research (2016), he discovered that environmental factors are quite effective on schools and this situation also affects the education quality. However, it should be remembered that not only school and administration but also families have a significant place in this process [27]. Therefore, education systems should have a structure encouraging innovation with a holistic approach and be the pioneer of innovation. The values such as solving, entrepreneurship and creativeness which take place in the philosophy of modern education systems are only possible by creating an innovative school spirit [15]. To create an innovative school spirit, effective use of innovation management is required.

Since organizations mostly have a permeable structure, a change occurring within organization creates a positive or negative effect like a living organism. One of these effects is organizational stress. With the meaning of the word, the concept of stress generally has a structure which indicates negative feelings and pressure. However it should be remembered that stress is categorized in two: positive stress and negative stress [25]. There are many factors that cause stress on individuals. One of these factors is the sources of organizational stress. Organizational stress is explained with many factors such as individual's excess workload, long working hours and insufficiency of wages [4]. In addition to this, the innovations occurring within organization is also effective as the concept of innovation has a confusing structure including uncertainty and may create contradictions. Thus, for the innovation management it is required to discover the one that innovation will be held and draw thoroughly the frame of the field that the innovation will be applied in [1]. In this way, stress-related responses of organizations will be minimized.

The aim of the research is to determine whether there is any meaningful relationship between school leaders' innovation management behaviors in their schools and the organizational stress or not and to contribute to science and researchers with the results based on the obtained data and to guide the school leaders in management practices.

\section{Methods}

In the research among the quantitative research methods, relational descriptive survey model was used. The relational descriptive survey model is a research model describing a situation or an occurred event as it is and indicating the relationship between the variables that cause this situation, their effect and degree [17]. The population of the research consists of 940 primary, 911 secondary and 649 high school teacher who works in Kocasinan, Kayseri. By getting stratified sampling in the research 400 inventories to primary and secondary school (for each of them), 250 inventories for high school were distributed and a feedback from 171 primary, 178 secondary and 168 high school has been provided. According to demographic variables the distribution of participants who participated in this research is shown in table 1.

Table 1. Information on the sample of the research

\begin{tabular}{lcc}
\hline & $\mathrm{N}$ & $\%$ \\
\hline Gender & 291 & 52,1 \\
Female & 268 & 47,9 \\
Male & & \\
Branch & 180 & 32,2 \\
Classroom Teacher & 379 & 67,8 \\
Branch Teacher & & \\
Professional Seniority & 79 & 14,1 \\
5 years and less & 105 & 18,8 \\
6-10 years & 135 & 24,2 \\
10-14 years & 240 & 42,9 \\
15 years and older & & \\
Type of School & 193 & 34,5 \\
Primary School & 188 & 33,6 \\
Secondary School & 178 & 31,8 \\
High School & 559 & 100,0 \\
\hline Total & & \\
\hline
\end{tabular}

As an inventory of data collection, for innovation management variable "Scale of Innovation Management at Schools" developed by Bülbül [8] which has 4 extents and 32 subjects, for organizational stress "Scale of Organizational Stress" developed by Pehlivan [26] which has 6 extent and 35 subjects were used in the research. For the analysis of obtained data, R 3.2.4 [30] and SPSS 21,00 packaged softwares were used. The method of confirmatory factor analysis (CFA reference) " $c f a$ " function which is defined in "lavaan" library version of $0.5-20$ was used in the analysis of construct validity of the inventories [31]. The suitability of the model to the data was determined by the analysis of compatibility values of Chi-square [16], Comparative Fit Index (CFI) $[9,18]$, Tucker Lewis Index (TLI) and Root 
Mean Square of Approximation (RMSEA) [9]. Cronbach Alpha values were calculated for the calculation of reliability. Coefficient of pearson correlation was calculated and tabulated for the relation between variables.

\section{Results}

Table 2. The fit index results of the measurement model

\begin{tabular}{lc}
\hline Minimum Function Test Statistic & 3660.609 \\
Degrees of freedom & 2099 \\
P-value (Chi-square) & .001 \\
& \\
Comparative Fit Index (CFI) & .950 \\
Tucker-Lewis Index (TLI) & .947 \\
& \\
RMSEA & .038 \\
\hline
\end{tabular}

The result of the fit index that is made regarding the validity of the research model related to the two variables "innovation management" and "organizational stress" which are required to be determined in the research is given in table
According to the results shown in table 2, for the compatibility of the research model created for the variables we want to measure, the value of P-value (Chi-square) being .001 indicates that our model gave us a more significant result than zero. In addition to this, the value of Comparative Fit Index (CFI) come out to be .950 and the value of Tucker-Lewis Index (TLI) come out to be .947 and this states that both of the values show us a good fit as they are over .95. According to $\mathrm{Hu}$ and Bentler [16], the more CFI and TFI values get .95 and higher the more it represents that the research is modelled so well. In addition to this, the value of RMSEA being .038 is also an indicator of the fit. According to Browne and Cudeck [7], if the value of RMSEA is .050 and lower, it represents that the fit increases. According to the statistical results that are made, it can be said that the research indicates a good fit.

The data obtained by making Confirmatory Factor Analysis (CFA) for the innovation management and the extent of organizational stress and the clauses which are the inventories used in the research is represented in table 3 and table 4. 2.

Table 3. The factor loads of the innovation management inventory

\begin{tabular}{|c|c|c|}
\hline \multicolumn{2}{|c|}{ Input Management ( $\rho=.816)$} & $\lambda$ \\
\hline 1 & I try/ he tries to get support from public institutions around the school for the innovation activities in the school. & .657 \\
\hline 2 & $\begin{array}{l}\text { I try/ he tries to get support from private institutions around the school (chambers, non-governmental organizations, etc.) for the } \\
\text { innovation activities in the school. }\end{array}$ & .667 \\
\hline 3 & I get/ he gets the support of an expert(consultant) from outside school about innovation. & .706 \\
\hline 4 & I allocate/ he allocates physical spaces in the school (meeting rooms and study rooms) to contribute the innovation activities. & .682 \\
\hline 5 & I provide/ he provides the supply of the tools and equipments that be used in the innovation process. & .718 \\
\hline \multicolumn{3}{|c|}{ Innovation Management $(\rho=.850)$} \\
\hline 6 & $\begin{array}{l}\text { I ensure/ he ensures the participation of the entire school personnel to a variety of events (in-service training, seminars, etc.) in } \\
\text { order to achieve external information that is necessary for the innovation. }\end{array}$ & .654 \\
\hline 7 & $\begin{array}{l}\text { I provide/ he provides the supply of resources such as books, magazines etc. in order to achieve external information that is } \\
\text { necessary for the innovation. }\end{array}$ & .697 \\
\hline 8 & I follow/ he follows the new developments in the field of education. & .647 \\
\hline 9 & I endeavor/ he endeavors for the innovations in the field of education to be understood by the entire school personnel. & .668 \\
\hline 10 & I work/he works for our school to have a clear vision of innovation which is known and shared by the entire school personnel. & .747 \\
\hline 11 & $\begin{array}{l}\text { I immediately stop/ he immediately stops the innovation projects if I feel/ he feels that the project will not make a positive } \\
\text { contribution to the school and the surrounding area. }\end{array}$ & .762 \\
\hline \multicolumn{3}{|c|}{ Organization Culture and Structure $(\rho=.889)$} \\
\hline 12 & I emphasize/ he emphasizes the importance of innovative approach to the entire personnel. & .723 \\
\hline 13 & $\begin{array}{l}\text { I explain/ he explains to the entire school personnel all the contributions of the innovation that will bring to the school and the } \\
\text { surrounding area. }\end{array}$ & .794 \\
\hline 14 & I appreciate/ he appreciates the innovative individuals at the school. & .742 \\
\hline 15 & I respect/ he respects the creative and innovative ideas of the entire school personnel. & .752 \\
\hline 16 & I clearly encourage/ he clearly encourages the learning and the effort leading to innovation. & .739 \\
\hline 17 & I endeavor/ he endeavors to keep the personnel who adopts and defends innovative ideas at school. & .785 \\
\hline \multicolumn{3}{|c|}{ Project Management $(\rho=.943)$} \\
\hline 18 & I adopt/ he adopts a consensus and a common approach before making a decision. & .711 \\
\hline 19 & I ensure/ he ensures innovation to be seen as a means of adapting to the environment and environmental integration. & .737 \\
\hline 20 & I/ he will be clear in the communications with the entire school personnel, students and parents during the innovation process. & .749 \\
\hline 21 & $\begin{array}{l}\text { By creating strong connections between the entire school personnel, I make/ he makes an effort to ensure the dominance of the } \\
\text { sense of embracing innovation. }\end{array}$ & .737 \\
\hline
\end{tabular}


22 I listen/ he listens to the voice of the school environment in all the innovations.

23 I expect/ he expects innovative ideas not from just a single person or a group but from the entire school personnel.

24 I try/ he tries to convince the entire school personnel that the risks taken for innovation will return as a gain.

25 I enable/ he enables the use of school resources efficiently in the innovation process.

26 I give/ he gives priority to the innovations that will make a contribution to the development of our school.

27 I pay/ he pays attention to the choice of the tools and equipment and resources which will be used in the innovation process. .763

$28 \mathrm{I} /$ he will be prepared for the unpredictable results of the innovation process at school.

29 I make/ he makes cost/benefit analysis of the gainings of the school which will be obtained from the innovation.

30 I always control/ he always controls the contributions of the school personnel who participated in this innovation process. .681

31 I ensure/ he ensures that all the personnel to work in cooperation with each other to develop innovative projects.

32 I develop/ he develops criteria to measure the effectiveness of our innovation projects.

NOTE: For each extent, the results of the internal consistency index of Raykov Rho are given inside the parentheses.

Table 4. The factor loads of the organizational stress inventory

\begin{tabular}{ll}
\hline Stress Sources Related to the Duty Structure $(\rho=.834)$ & The length of the working hours \\
1 & Inadequacy of the wages \\
2 & Having less opportunity to get promotion \\
3 & Work which is boring \\
4 & Crowded workplace \\
5 & Noisy work environment \\
6 & Poor lighting in the workplace \\
7 & The weight of the workload \\
8 & What is expected from you being unclear
\end{tabular}

Stress Sources Related to the Structure of Authority ( $\rho=.887$ )

10 Legislation which is complicated .741

11 Managers who do not encourage .727

12 The lack of authorization .709

13 The responsibilities which raise concerns .692

14 The obligation to provide important decisions .728

$15 \quad$ Work-related responsibilities and authority that are not clearly defined .738

16 The absence of injustice while assessing the staff .661

17 Conscientious responsibility created by the decisions .629

Stress Sources Related to the Production Structure $(\rho=.828)$

18 The obligation to do the expected work in a very short time .731

19 The lack of tools and equipments used while working .633

20 Inability to fully use the skills on the work that is done .707

$21 \quad$ Not receiving a recompense for one's work .644

22 Difficulty in being able to remain neutral while on duty .780

Stress Sources Related to the Structure of Aggregation $(\rho=.936$ )

23 Unrest in the business environment 857

$24 \quad$ Incompatibility with the colleagues .856

$25 \quad$ Conflict with the superiors .874

$26 \quad$ Conflict with the subordinates .846

27 Unfair demands of the students' parents .711

28 The lack of common interests with colleagues .795

29 Gossiping in the workplace .816

Stress Sources Related to the Role Structure $(\rho=.794)$

30 Different people at the workplace having different expectations than you have .845

31 The difference between your personality and your job .776

Stress Sources Related to the Cultural Structure $(\rho=.816)$

32 Despondency .814

33 The differences in political views with colleagues .740

34 The obligation to obey the rules established by colleagues .729

35 The low status of the profession

NOTE: For each extent, the results of the internal consistency index of Raykov Rho are given inside the parentheses. 
Table 5. Correlation results

\begin{tabular}{|c|c|c|c|c|c|}
\hline & \multicolumn{5}{|c|}{ Innovation Management } \\
\hline & Dimensions & Input Management & Innovation strategy & $\begin{array}{c}\text { Organization Culture and } \\
\text { Structure }\end{array}$ & $\begin{array}{c}\text { Project } \\
\text { Management }\end{array}$ \\
\hline \multirow{6}{*}{$\begin{array}{l}\text { Organization } \\
\quad \text { Stress }\end{array}$} & Duty Structure & $-0,077$ & $-0,033$ & $-0,069$ & $-0,060$ \\
\hline & Authority Structure & $-0,038$ & 0,007 & $-0,012$ & $-0,062$ \\
\hline & Production Structure & 0,024 & 0,076 & 0,059 & 0,032 \\
\hline & Aggregation Structure & $-0,023$ & $-0,032$ & $-0,106^{*}$ & $-0,066$ \\
\hline & Role Structure & $-0,052$ & $-0,045$ & $-0,103^{*}$ & $-0,056$ \\
\hline & Culture Structure & $-0,088$ & $-0,097$ & $-0,154 * * *$ & $-0,107^{*}$ \\
\hline
\end{tabular}

Note: It is meaningful for $* \mathrm{p} \leq .050,{ }^{* *} \mathrm{p} \leq .010$ and ${ }^{* * *} \mathrm{p} \leq .001$.

According to the data in table 3, when the data related to CFA applied for innovation management inventory is analyzed, it is seen that the factor load of each subject is ( $\lambda$ ) .64 and higher. These values represent that they are sufficient with regard to the validity of the subjects. Looking at the values of Raykov Rho, it is seen that the extent of the input management is .816 , the extent of innovation management is .850 , the extent of organizational culture and structure is .889 and the extent of the project management is .943. According to Raykov [28,29], it is accepted that the more the obtained results get .70 and higher, the more reliability and validity increases that much. These results indicate that inventory of innovation management has the conditions for reliability and validity needed for the research.

The results of the confirmatory factor analysis (CFA) for the organizational stress extent which is another variable of the research and for its clauses are represented in table 4.

According to the data given in table 4, when the data related to CFA which is applied for the organizational stress inventory is analyzed, it is seen that the load of each subject is $(\lambda) .46$ and higher. These values represent that they are sufficient with regard to the validity of the subjects. Looking at the values of Raykov Rho, it is seen that the extent of Stress Sources Related to the Duty Structure is .834 , the extent of Stress Sources Related to the Structure of Authority is .887, the extent of Stress Sources Related to the Structure of Production is .828 and the extent of Stress Sources Related to the Structure of Aggregation is .936, the extent of Stress Sources Related to the Role Structure is .794 and the extent of Stress Sources Related to the Cultural Structure is .816. According to Raykov [28,29], it is accepted that the more the obtained results get .70 and higher, the more reliability and validity increases that much. These results indicate that organizational stress inventory has the conditions for reliability and validity needed for the research.

For the relation between innovation management and organizational stress, the correlations of the sub extent was calculated and represented in table 5 .

According to the results in table 5, when the relation between innovation management and organizational stress is analyzed it is seen that the variable of innovation management and the variable of organizational culture and structure extent and organizational stress are in a low-level, negative and significant relation between the sub extents of aggregation structure (for $\mathrm{r}=-0,106$ and $\mathrm{p} \leq .050$ ), role structure ( for $\mathrm{r}=-0,103$ and $\mathrm{p} \leq .050$ ) and culture structure ( for $\mathrm{r}=-0,154$ and $\mathrm{p} \leq .001$ ). Also, it is seen that project management which is a sub extent of the variable of innovation management and cultural structure extent of organizational stress have a low-level, negative and significant relation.

\section{Discussion}

When the results obtained from the research are analyzed, it is seen that there is a low-level, negative and significant relation between innovation management and organizational stress. Increase of the innovation level in an organization has an impact on a significant structure contributing to the reduction of stress within the organization. It should not be forgotten that the most significant driving force in an organization is the leader. The behaviors of the leaders have a direct influence on this process. About this subject, in the research of Lin, Su \& Higgins [20] it is stated with similar expressions that innovation management should be used effectively in order to maintain an effective and dynamic management approach. Uğurlu, Kiral \& Aksoy [37] too, have emphasized in their researches that the management is important to maintain an unending and dynamic process most effectively for all employees of the organization and for the organization. In this way it can be contributed to the efficiency of the education process. In the research of Manea, A.D. [23], it is stated that school management being effective in the innovation management improve the quality of school and contribute to the performance. Though innovation management creates an uncertainty in an organization, in fact it is an approach reducing the problems of the organization and preventing the occurrence of problems. This situation is seen as a factor preventing stress to be experienced by the organization and ensuring the reduction of the stress level. In researches that are made, it is demonstrated that there are many variables affecting the level of stress. Pehlivan [26], in his research named "Stress Sources in Education Management', aimed to demonstrate the situations causing stress. According to the research, conditions such as insufficient wages, injustice, 
incompetence and lack of tools and equipments put stress on managers. In the research of Bertan [5], the relation between organizational stress and organizational commitment was analyzed and low-level, significant relations were detected. In their researches Töremen \& Tan [35] and Titrek[32] has found that the concept of justice has a significant and negative relation between procedural and distributive justice and work. In addition to this, ethical climate in organizations also has an impact on stress. Y1lmaztürk [38] in his research has found that organizational stress levels vary according to the variables such as title, seniority and personality. As is seen, there are many variables having an impact or constituting a source on organizational stress. We tried to reveal whether there is a relation between the organizational stress and the variable of innovation management or not. While it is known that the school managers' viewpoints related to these two significant concepts can be increased most effectively with education, in the research of Toytok \& Çelepçıkay [34] it is seen that school managers do not lean towards education.

\section{Conclusions}

According to the date obtained from the research, firstly it is seen that our research modeling fit in a valid and reliable structure. This situation shows us that we measured the structure accurately we wanted to measure in the research. Looking at the other results obtained from the research, it is seen that there is a significant relation between the innovation management behaviors of school leaders and organizational stress sources. It is found that this significant relation is negative and in a low-level. When the extent which the significant relations take place in is analyzed, it is seen that this significance is between the organizational culture and structure which is a sub extent of the variable of innovation management, and aggregation, role and structure which are the extents of the variable of organizational stress. The strongest relation between the extents of organizational culture is in the extent of cultural structure. According to this, it can be said that the increase of the innovation management behaviors of school leaders in an organization create a significant impact reducing stress in an organizational structure.

In conclusion, our school leaders need to provide an effective process of innovation management so that our schools within an open and social organization system structure can keep up with the changing and renovating world and reduce the stress level of our educational organizations. In this way, our educational organizations provide a significant contribution to the path of creating a sustainable effectiveness.

\section{Acknowledgements}

According to the results obtained from the research and the results emerging in parallel with other researches, an experimental study related to the concepts of innovation management and organizational stress can be conducted with the school leaders. According to the experimental results, workshops can be done with the school leaders.

\section{Note}

*The abstract of this paper was presented at 2nd International Conference on Lifelong Learning and Leadership for All (ICLEL-16), in Liepaja on July, 21-23, 2016.

\section{REFERENCES}

[1] Adams, B., Bessant, J. ve Phelps, R. (2006). Innovation management measurement: a review. International Journal of Management Reviews, 8(1), 21-47.

[2] Adair, J. (2007). Leadership for innovation. London: Kogan Page.

[3] Argon, T., \& Dilekçi, Ü. (2014). The Relationship Between Teachers' Perceptions on School Principals' Management Styles and The Schools Corporate Reputation. Turkish Studies, volume $9 / 2$ winter

[4] Baltaş, A. ve Baltaş, Z., (2006). Stress and Coping Ways. İstanbul: Remzi Publishing.

[5] Bertan, B. (2012). The relation between organizational stress and organizational commitment of school principals which work in Public and Private Primary Schools (Pendik sample) İstanbul: Yeditepe University Institute of Social Sciences. M.A. Thesis, Educational Administration and Supervision Master's Program

[6] Birkinshaw, J. M., \& Mol, M. J. (2006). How management innovation happens. MIT Sloan Management Review, Vol.47(No.4), 81-88. Retrieved from

http://sloanreview.mit.edu/the-magazine/2006-summer/47415 /how-management-innovation-happens

[7] Browne,M.W., \& Cudeck, R. (1993). Alternative ways of assessing model fit. In K.A. Bollen \& J.S. Long (Eds.), Testing structural equation models (pp. 136-162). Newbury Park, CA: Sage

[8] Bülbül, T. (2012). Developing a Scale for Innovation Management at Schools: A Study of Validity and Reliability. Educational Sciences: Theory \& Practice - 12(1) Winter 168-174

[9] Byrne, B.M. (1998), Structural Equation Modeling with LISREL, PRELIS and SIMPLIS: Basic Concepts, Applications and Programming. Mahwah, New Jersey: Lawrence Erlbaum Associates.

[10] Deniz, N., Noyan, A., \& Ertosun, Ö.G. (2015). Linking Person-job Fit to Job Stress: The Mediating Effect of Perceived Person-organization Fit. 11th International Strategic Management Conference. - Social and Behavioral Sciences Volume 207, 20 October 2015, Pages 369-376 
[11] Douglas, M. A., Overstreet, R. E., \& Hazen, B. T. (2016). Art of the possible or fool's errand? Diffusion of large-scale management innovation. Business Horizons.

[12] Edwards, T. (2000). Innovation and organizational change: developments towards an interactive process perspective. Technology Analysis \& Strategic Management, 12(4), 445-464.

[13] Epçaçan, C. (2014). Opinions Of Primary And Secondary School Teachers And Administrators On The $4+4+4$ Education System (Siirt Sample). Ekev Journal of the Academy, winter volume 58

[14] Flint, D. J., Larsson, E., Gammelgaard, B., \& Mentzer, J. T. (2005). Logistics Innovation: a Customer Value-Oriented Social Process. Journal of Business Logistics, 26(1), 113-147.

[15] Göl, E., \& Bülbül, T. (2012). The Perceptions of the Teachers Regarding the Innovation Management Efficacies of the Primary School Administrators. Mersin University Journal of the Faculty of Education, Vol. 8, Issue 2, August 2012, pp.97-109.

[16] Hu, L.T. and Bentler, P.M. (1999), "Cutoff Criteria for Fit Indexes in Covariance Structure Analysis: Conventional Criteria Versus New Alternatives," Structural Equation Modeling, 6 (1), 1-55.

[17] Kaya, A., Balay, R., ve Göçen, A. (2012). Educational Evaluation, Measurement and Research The level of teachers' knowing, application and training need on alternative assessment and evaluation techniques. International Journal of Human Sciences [Online]. (9)2, 1229-1259.

[18] Kline, R.B. (2011). Principles and practice of structural equation modeling (Third edition). New York: The Guilford Press

[19] Korkmaz, M. (2005). Effects Of Leadership Styles and Emotions on Teachers' Performance. Educational Administration: Theory and Practice, Summer 2005, Volume 43, P. 401-422

[20] Lin, H.F., Su, J.Q., \& Higgins, A. (2016). How Dynamic Capabilities Affect Adoption Of Management İnnovations. Journal Of Business Research, 69 (2016) 862-876

[21] Mateescu, A., \& Chraif, M. (2015). The Relationship between Job Satisfaction, Occupational Stress and Coping Mechanism in Educational and Technical Organizations. Procedia - Social and Behavioral Sciences, Volume 187, 13 May 2015, Pages 728-732

[22] Melnyk, S. A., Ritchie, W. J., \& Calantone, R. J. (2013). The case of the C-TPAT border security initiative: Assessing the adoption/persistence decisions when dealing with a novel, institutionally driven administrative innovation. Journal of Business Logistics, 34(4), 289-300. Council of Supply Chain Management Professionals.

[23] Manea, A.D. (2015). Innovation in the management of educational institutions. Procedia - Social and Behavioral
Sciences 209, $310-315$

[24] Özdemir, S., \& Cemaloğlu, N. (2000). Eğitimde örgütsel yenileşme ve karara katılma. Milli Ĕ̆itim Dergisi,146, 54-63.

[25] Pehlivan, İ. (2002). İş Yaşamında Stres. Ankara: Pegem Yayınlar1.

[26] Pehlivan, İ. (1993). Eğitim Yönetiminde Stres Kaynakları. Doktora Tezi, Ankara Üniversitesi Eğitim Bilimleri Enstitüsü, Ankara, ss.4-63.

[27] Pesen, A. (2015). Metaphors That Parents Assing To The Concept Of "Child". Turkish Studies Journal, volume 10/15 Fall 2015, P. 731-748

[28] Raykov, T. (1997). Estimation of composite reliability for congeneric measures. Applied Psychological Measurement, 21 , 173-184.

[29] Raykov, T. (2004). Behavioral scale reliability and measurement invariance evaluation using latent variable modeling. Behavior Therapy, 35, 299-331

[30] R Core Team (2016). R: A language and environment for statistical computing. R Foundation for Statistical Computing, Vienna, Austria. URL https://www.R-project.org/.

[31] Rosseel, Y. (2012). lavaan: An R Package for Structural Equation Modeling. Journal of Statistical Software, 48(2), 1-36. URL http://www.jstatsoft.org/v48/i02/.

[32] Titrek, O. (2009). The level of organizational justice in schools according to school types. International human sciences journals. volume $6 / 2$

[33] Toytok, E. H., Korkmaz, M., \& Anik, S. (2016). Environmental Conditions of the City in which Teachers Serve and their Organizational Commitment Perception Levels. Anthropologist, 24(1), 90-96.

[34] Toytok, E. H., \& Çelepçıkay, E. (2016). A Qualitative Research About Perspectives Related To Master Education Of School Principals Serving In Siirt. Journal of Siirt University Institute of Social Sciences, (04).

[35] Töremen, F., \& Tan, Ç. (2010). Justice İn Education Organizations: A Conceptual Analysis. Dicle University Journal Of Education Faculty 14 (2010), 58-70

[36] Trott, P. (2005). Innovation management and new product development (3rd Edition). London: Prentice Hall.

[37] Uğurlu, Z., Kıral, E., \& Aksoy, G. (2011). İlköğretim Okul Yöneticilerinin Görüşlerine Göre Öğretmenlerin Sosyalleşmesinde Kullandıkları Örgütsel Sosyalleşme Strateji ve Taktikleri. Ankara: Siyasal Kitapevi.

[38] Y1lmaztürk, A. (2013). Prımary Schools' Managers' Organizational Stress Sources And Keys For Solution (Istanbul City Sultanbeylı District Sample). Istanbul: Yeditepe University Institute Of Social Sciences. M.A. Thesis, Educational Administration And Supervision Master's Program. 